Meta

Journal des traducteurs

Translators' Journal

\title{
The Translatability of Arabic Jokes into English
}

\section{Mohammad K. El-Yasin}

Volume 42, numéro 4, décembre 1997

URI : https://id.erudit.org/iderudit/002706ar

DOI : https://doi.org/10.7202/002706ar

Aller au sommaire du numéro

Éditeur(s)

Les Presses de l'Université de Montréal

ISSN

0026-0452 (imprimé)

1492-1421 (numérique)

Découvrir la revue

Citer cet article

El-Yasin, M. K. (1997). The Translatability of Arabic Jokes into English. Meta, 42(4), 670-676. https://doi.org/10.7202/002706ar

\section{Résumé de l'article}

Cet article traite de la possibilité de traduire des blagues linguistiques de l'arabe au français. Les blagues linguistiques sont fondées sur des incongruités de la langue- L'auteur étudie un échantillon de blagues arabes basées sur des calembours, des homonymes, des expressions, le rythme et la collocation et conclut à l'impossibilité de les traduire. Les problèmes culturels et surtout linguistiques sont énormes et bien que les blagues situa-tionnelles arabes puissent être traduites en anglais, celles découlant d' "accidents linguistiques" propres à l'arabe ne trouvent pas d'équivalents acceptables en anglais. 


\title{
THE TRANSLATABILITY OF ARABIC JOKES INTO ENGLISH
}

MOHAMMAD K. EL-YASIN

Yarmouk University, Irbid, Jordan

\begin{abstract}
Résumé
Cet article traite de la possibilité de traduire des blagues linguistiques de l'arabe au français. Les blagues linguistiques sont fondées sur des incongruités de la langue. L'auteur étudie un échantillon de blagues arabes basées sur des calembours, des homonymes, des expressions, le rythme et la collocation et conclut à l'impossibilité de les traduire. Les problèmes culturels et surtout linguistiques sont énormes et bien que les blagues situationnelles arabes puissent être traduites en anglais, celles découlant d" «accidents linguistiques» propres à l'arabe ne trouvent pas d'équivalents acceptables en anglais.
\end{abstract}

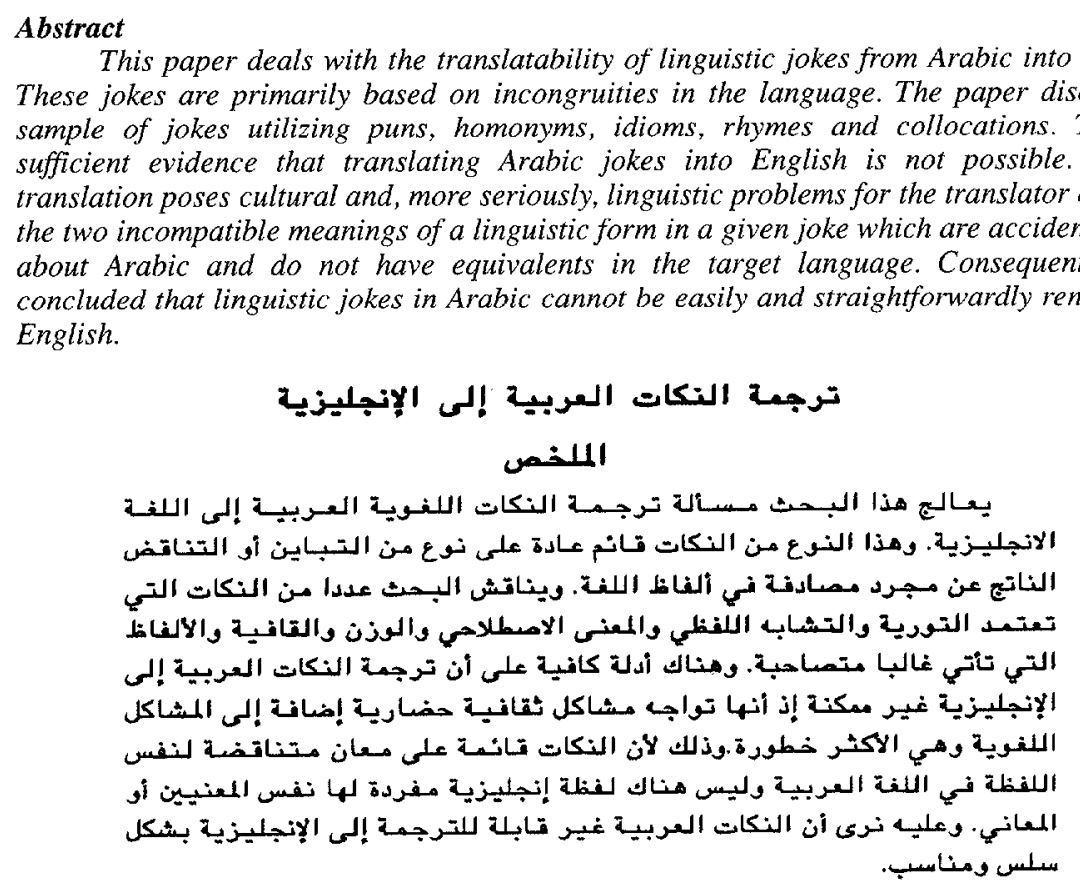

\section{INTRODUCTION}

Wilson (1979: 2) defines a joke "as any stimulation that evokes amusement and that is experienced as being funny." Further, he states that a joke as well as humor involves two incongruous, incompatible, or contradictory meanings which are combined 
in one entity (1979:11). He illustrates incongruity by citing the following two sentences $(1979: 20)$ :

(1) Kuwait is rich in oil

(2) India is rich in poverty

In (1), the two meanings of 'is rich in' are compatible (i.e., abundance = wealth), thus, a conjunctive ambiguity is obtained. In (2), however, the two interpretations are incompatible or incongruent (i.e., abundance $\neq$ wealth); a disjunctive ambiguity is thus obtained. Accordingly, in any situation we need to be able to decipher the meanings of a given joke if we want to attain amusement and laughter. In this paper, a narrower definition than Wilson's is adopted restricting jokes to short narratives rather than "any stimulation."

If a joke makes use of a word or a group of words intended to express two incongruent meanings arousing amusement and laughter (what we will call a linguistic joke), can this linguistic joke be translated from one language into another? Newmark (1988: 217) maintains that puns (which to him are roughly equivalent to our linguistic jokes) can be readily translated:

If they are based on Graeco-latinisms that have near equivalents in the source and target languages; [...] thus there would be no difficulty in translating both senses of words like point, animal, infernal, if a pun were made on them in French and, again, the material and figurative sense of a word often corresponds with one-to-one equivalents, such as 'sleep', 'die', 'be born'.

Newmark goes on to say that if a joke or pun is meant to evoke amusement, "it can sometimes be 'compensated' by another pun on a word with a different but associated meaning" (p. 217). On the contrary, when the two interpretations of a joke are more significant than the word or words, they are sometimes translatable "by reproducing the two senses in an incongruous way; thus (dans le panneau) referring to a misleading signboard system introduced into a city (panneau, (a) 'a sign board', panneau indicateur; (b) 'a trap', tomber dans le panneau) could be translated as 'the signboard mess"' $(1988: 217)$. Finally, Newmark concludes that "the translation of puns is of marginal importance and of irresistible interest" (1988: 217).

Nevertheless, Newmark (1988: 107) claims that "all jokes are translatable, but they do not always have the same impact." Newmark (1988: 108) suggests three methods for translating a word in a joke with two meanings. First, the translator should try to find a TL word expressing the two meanings in the SL. Second, if the first method does not prove successful, the translator should either distribute the two meanings of the word "over two or more lexical units," or sacrifice one of the two meanings. Finally, the translator can use a "synonym with a comparable double meaning."

The purpose of this paper is to shed more light upon the translation of jokes. It specifically aims at demonstrating whether or not jokes in Arabic can be translated into English. Therefore, the paper will try to answer the following questions:

First, are Arabic jokes translatable into English? jokes?

Second, what problems does a translator encounter in Arabic-English rendering of

Finally, can Newmark's $(1981,1988)$ claims about the rendering of jokes be sustained in Arabic-English translation?

This paper aims to be significant in three ways. First, it should attract researchers' attention to this issue in translation since it seems very little research (see Newmark 1981, 1988) has been done in this domain. Second, Arabic jokes have not been, to the best of 
our knowledge, studied in relation to translation. They should thus be explored because studying them would make translators and others interested aware of what problems, if any, are involved in Arabic-English translation of jokes. Finally, it is significant for the theory of translation since it attempts to verify the general claims made regarding the translatability of jokes or puns.

\section{THE TRANSLATABILITY OF JOKES}

One way of classifying jokes is to use as our criterion whether the joke derives its incongruity from the situation or from a linguistic fact. Generally speaking, one would expect those based on incongruity in situation to be translatable with some minor problems. Of these problems is the cultural difference between the respective speech communities of the two languages in question. Different cultures find different things humorous (Hockett 1972: 157); what is humorous for an Arab is not necessarily humorous for an Englishman or an American. But this cultural transfer problem might pertain to all translation not only to jokes and it remains reasonable to maintain that jokes based on incongruity in situation are more or less translatable. For example, the Arabic riddle-joke asking about the similarity between an orange and a train does not lose much when its punch line is translated into English: "Neither of them can swim." The incongruity here is based on the universal character of comparison or contrast: one normally compares or contrasts things which are so similar that a special effort has to be made to keep them apart. This does not apply to an orange and train. However, this is not funny enough in itself to be a joke and so the punch line helps when it negates the ability of both to swim. Negation is appropriate only when the proposition expressed by the affirmative statement is suspected to be true and the speaker ascertains that it is not. In our case, the negative would imply that someone suspects or claims oranges and trains can swim. However, as inanimate objects, oranges and trains are not expected by anybody to swim. Hence, the incongruity of the negation.

Our emphasis in this paper, on the other hand, will be on linguistic jokes, i.e, those which are based on some incongruity resulting from an accidental feature in the design of the language. In one type, the build-up of the joke creates a context in which one interpretation of a linguistic from is reasonable and another is suppressed, i.e, not allowed by the context. This suppressed sense (Katz 1972: 97) is then brought to the fore by the punch line - the climax of the joke. In another type, rhymes play an important role. Typically a slot which can be filled with a rhyming expression is filled by an incongrous item leaving it to the hearer to think of the appropriate rhyming item, which is usually obscene. Idioms and names also play their role.

In the following paragraphs, we will look into the possibility of translating these jokes from Arabic into English. Examples of jokes utilizing puns, homonyms, idioms, rhymes and collocations will be discussed. In all cases, the accidental linguistic feature will be related to the source of humor in the joke.

One linguistic feature suitable for word play is the existence of more than one sense of the same phonological form. Hence, punning can be utilized to generate humor. One Jordanian joke tells of a Moslem sheikh and a Christian priest in a car. The driver is going so fast around a corner that the passengers are shaken. The priest remarks:

$$
\begin{array}{llll}
\text { yil'an } & \text { 'ar } \underline{d} & h a & \text { al-laffih } \\
\text { it-execrates } & \text { [the]-good-repute } & \text { [of]-this } & \text { he-curve }
\end{array}
$$

"Cursed be this curve." 
This remark is not as innocent in Arabic as it is in English since laffih can also mean turban, especially one worn by Moslem sheikhs. Therefore, although the priest is complaining about the rough ride, the audience can take his words as calling the shiekh bad names. Of course, in a predominantly Moslem society, the sheikh should be able to find a chance to pay back in kind. Indeed, at a bad bump he complains:

$$
\begin{array}{lllll}
\text { yil'an } & \text { 'abuunaa } & \text { ' } a & \text { ha } & \text { al-rukba } \\
\text { it-execrates } & \text { father- our } & \text { for } & \text { this } & \text { he-ride }
\end{array}
$$

yil' an abuuna is a slang idiom meaning something close to Unlucky we or Damn us or the like. However, the reference to our father, the priest, is also clear and Cursed be the priest is a possible interpretation.

The fact that laffih, which is utilized in the first half of this joke, means both turban and curve is a sheer coincidence, as becomes especially apparent when compared to other languages. Our attempt to transfer this joke into English by means of an explanation is too cumbersome to be a joke and simply spoils its humorous effect. To render it into a smooth English narrative using either curve or turban would simply ignore the sense not chosen and the joke would be lost.

Akin to the ambiguity of a given word is the phenomenon of homophony. Homophonous form like $\underline{h} a b b$ 'grain' and $\underline{h} a b b$ 'he fell in love' can give rise to jokes like:

$\begin{array}{llll}\text { fiih } & \text { waahad } & \underline{h a b b} & \underline{\text { tahanuuh }} \\ \text { here-is } & \text { one } & \text { fell-in-love/grain } & \text { they-ground-him/it }\end{array}$

The sense of grain is suppressed following fiih waahad which most naturally would be interepted as "there was someone." The appropriate sense is "fell-in-love." The shock comes with the word tahanuuh "they turned him into flour" which forces the hearer to bring to the fore the suppressed, incongruous sense of grain. Another joke begins:

fiih waahad habb

The use of waahad rather than waahad is an indication of an Arabic accent where the voiceless pharyngeal fricative $/ \underline{h} /$ is pronounced as $[\mathrm{h}]$ such as in some Sudanese dialects. This leads the hearer to take $h a b b$ as the dialect form of $h a b b$ and the whole sentence is taken to mean "Someone fell in love." However, the joke continues:

taffuuh

extinguished-they-him

"They extinguished him."

This new sentence forces the hearer to reconsider $h a b b$ and to take it as $h a b b$ with the /h/ not the $/ \underline{h} /$, which means "caught fire." The two sentences are now taken to mean "Someone caught fire. They extinguished him," which is clearly not a joke in English. In English the translator has to choose between "Someone fell in love. They extinguished him," which is rather absurd, and "Someone caught fire. They extinguished him," which reports a tragic incident rather han telling a joke.

Besides phonological features, idiomatic expressions can be utilized in joking. Idioms are especially rich in potential humor since their meanings do not make sense in terms of the meanings of their components. Arabic inkasar xaatruh, lit. "his spirit got broken," idiomatically means "he was cast down;" no physical breaking is involved. So when the joke tells of somebody falling off the wall and breaking something: 
$\begin{array}{llllll}\text { fiih } & \text { waahad } & \text { wigi' } & \text { 'an } & \text { heet } & \text { inkasar... } \\ \text { there-is } & \text { someone } & \text { fell-down } & \text { off } & \text { wall } & \text { broke... }\end{array}$

one would anticipate a leg, an arm, a rib, etc. But the joke surprises the hearer with xaatruh "his spirit;" the idiom is brought to the fore and incongruity and, hence, humor obtains.

In the sheikh and priest joke mentioned already, the idiomatic expression yill'an abuuna makes the second half of the joke possible.

Rhymes can also be utilized in joke telling. One Arabic joke tells of two people boasting about their ability to say verse. One of them challenges the other to show his talent. The latter says:

$\begin{array}{lll}\text { nizlit } & \text { latisbah } & \text { liizaa } \\ \text { went-down-she } & \text { to-swim } & \text { Liza } \\ \text { wislit } & \text { Imayyih } & \text { lrukbthaa } \\ \text { came-to } & \text { the-water } & \text { to-knee-her }\end{array}$

"Liza went to swim

The water reached her knee."

These two lines should have the same rhythm and should rhyme if they are to count as verse. The word lrukbtha neither rhymes with liiza, nor does it fit the meter of the line. Hearers always think of tiiza "her ass" to correct the defect. But tiiza is a taboo word not to be used in polite settings, and so it is left unsaid for the smart hearer to come up with. When this 'untalented' poet is told that his verse does not work, he responds that there was not enough water to do the job, without, of course, mentioning the taboo word.

Related to idioms are names of things which are not always precise scientific definitions of the objects or concepts they name. 'umm 'arba' a warib'iin lit. "that which has forty-four" is the centipede. The riddle starting with the question, "What is twentytwo over twenty-two?" is intended as a joke and derives its humor from the incongruity of the apparently mathematical question and the answer, which is the funny:

$\begin{array}{llll}\text { 'umm 'arba'a warib'iin haattah 'ijir 'a 'ijir } \\ \text { that-which-has four and-forty } & \text { putting leg on leg }\end{array}$

This joke is made possible only if the name is taken too seriously. It is based on the fact that Arabic gives this creature forty-four legs regardless of scientific reality. Would the joke in English be based on he name whose etymology means "a hundred feet?" Would the joke then begin "What is fifty over fifty?" We do not think so, since the etymology is not a synchronic fact about English, that is, native speakers of English do not think of a centipede as the "hundred-legged one." In contrast, an Arabic speaker has little alternative to 'umm 'arba' a warib' iin if he wants to say "that which has forty-four."

Like idioms, collocations can be utilized in joke telling. One example is a joke that starts:

$\begin{array}{llll}\text { marra } & \text { kaan } & \text { fiih } & \text { waahad... } \\ \text { once } & \text { was } & \text { there } & \text { one... }\end{array}$

"Once, there was someone..."

The usual context here is the beginning of a narrative as in English "Once upon a time...," but our joke continues:

$\begin{array}{lll}\text { Oneen } & \text { Oalaatih } & \text { 'arab'a } \\ \text { two } & \text { three } & \text { four }\end{array}$


Selecting in this way the other set of collocations of which "one" is a member. Notice here that "one" in English is a member of the counting list but "someone," or more usually "a man," "a woman," etc., is used in the other context of starting a narrative. Hence, the impossibility of translation.

One last joke which is interesting to the Arabic-English translator is in fact a composite one. It is not a joke with a build-up leading to a punch line, but one where, after the build-up, the teller keeps coming with one funny point after the other (cf. Hockett 1972: 156). The joke tells of a party in which the late Egyptian President, Nasser, is introduced to members of the diplomatic community in Cairo. The different ambassadors are given names which sound typical of their nationalities but which are dirty words in Arabic. So the Ethiopian is eero gaasii gaasii (penis-his hard hard, "his penis is real hard"), the Algerian ahmar buu tafliisha (red with flat-head "red with a flattened head"), the Russian valantiinaa kusmantuuf (Valentina cunt-shaved, "Valentina of the plucked cunt") the Italian firdinaandoo mdandileeroo (Ferdinando hanging-penis-his, "Ferdinando is letting his penis hang down") the Romanain niikoo bala xoof (fuck-him without fear, "Fuck him without fear!"), and the like.

At no point does the joke seem to have a natural point. The joke is made possible, however, because of sheer accidental phonological facts of Arabic, namely, that some obscene expressions sound like words or names in other languages. There does not seem to be any need for elaboration on the translatability of this joke.

These are only representative examples of jokes based on some linguistic phenomenon. Such phenomena are always accidents in the design of the Arabic language. One does not expect the same accidents to obtain in English and this makes the jokes impossible to translate.

\section{CONCLUSION}

This paper has examined the translatability of Arabic jokes into English. Jokes based on incongruity in situation have been found to be translatable with minor problems like cultural transfer. However, linguistic jokes pose a serious problem. The sample of those jokes included a word or a group of words which evoke some kind of incongruity based on some linguistic fact. There is evidence in the discussion provided above that Arabic linguistic jokes cannot be readily translated into English because the two incompatible meanings of the linguistic form in a given joke are accidental facts about Arabic and do not have equivalents in the target language. Thus, the absence of equivalent linguistic units in English constitutes a serious problem for the translator. This finding clearly contradicts Newmark's (1981, 1988) claim that jokes, all jokes, are translatable. Further, even if we accept Newmark's claim that the translator can use a "synonym with a comparable double meaning," translating the jokes out of Arabic loses the point, because they are jokes about the Arabic language. Nor can we sacrifice one of the two meanings, following Newmark (1981), because, in so doing, we would distort and spoil the ultimate goal of the joke which is to evoke amusement and laughter based on the existence of the two meanings not just one of them; consequently, the intentions of the joke-teller would not be communicated.

Finally, the paper has demonstrated that the translation of Arabic jokes argues against Nida's (1964: 159) notion of formal equivalence. This is the case since in such cases formal correspondences, be they sentences, words, expressions, or concepts, are simply not there in the target language to help the translator "to eproduce as literally and meaningfully as possible the form and content" of the source language jokes. 


\section{REFERENCES}

HOCKETT, Charles C. (1972): "Jokes", M. Estellies Smith (Ed.), Studies in Linguistics in Honor of George L. Trager, The Hague, Paris, Mouton, pp. 153-178.

KATZ, Jerrold J. (1972): Semantic Theory, New York, Evanston, San Francisco, London, Harper and Row.

NEWMARK, Peter (1981): Approaches to Translation, Oxford, Pergamon Press.

NEWMARK, Peter (1988): A Textbook of Translation, New York, Prentice Hall.

NIDA, E. A. (1964): Toward a Science of Translating, Leiden, E. J. Brill.

WILSON, Christopher P. (1979): Jokes: Form, Content, Use and Function, London, New York, Toronto Sydney, San Francisco, Academic Press. 